\title{
PROLOGUE: THE HANGING OF SHEIKH MUJIB'S ASSASSINS
}

bout three decades ago I met a man who calmly told me how he had
organized the massacre of a family. There was no sense of remorse in his confession. He was bragging about it, even grinning as he spoke to me.

I was a young reporter at that time, on assignment in Dhaka ${ }^{\star}$, trying to figure out what had gone wrong with Bangladesh. Fifteen years earlier, as a schoolboy in India, I had followed its blood-splattered struggle for independence. I remembered the images of ten million people who had crossed the border seeking refuge in India; I had collected funds for the refugees by staging a play in Bombay, as the city I grew up in was known at that time; we shouted 'Joy Bangla', the Bangladeshi cry for independence, for no apparent reason (10-year-old kids do such things); and we eagerly listened to the radio and read newspapers over two weeks in December, as India defeated the Pakistani army, assisting Bangladeshi Mukti Bahini forces to gain independence. During those days, I remember going with my family to the railway station with home-cooked food for Indian soldiers going to the front.

The man I was interviewing that day in Dhaka lived in a well-appointed home in Banani, a tony part of Bangladesh's capital. Soldiers protected his house, checking the bags and identification of all visitors. A week earlier he had been a presidential candidate, losing by a huge margin to the eventual winner, President Hussain Muhammad Ershad.

The man I met wore a Pathani outfit that looked out of place in a country where civilian politicians tended to wear white kurtas with black waistcoats if they belonged to the Awami League, and safari suits if they were part of the Bangladesh Nationalist Party, while working class men on the streets went about in lungis. The Pathani outfit was more in tune with what men from Pakistan wore, and as I was to learn later, many Bangladeshis who had lost their

^Dacca was renamed Dhaka in 1983; it has been spelt accordingly in different chapters of the book. 
loved ones during the war hated that outfit, just as they hated the Urdu slogan 'Bangladesh Zindabad'. They preferred 'Joy Bangla' in Bengali.

The man I had come to interview had a thin moustache and wore goldrimmed glasses. He stared at me eagerly as we spoke, curious about the notes I was taking, trying to read what I was writing in my notepad. He sat straight on the sofa, his chest thrust forward, as if he was still in uniform. He looked self-assured and confident; not like someone who had overwhelmingly lost the presidential poll. He was part of a high stakes game, and he looked as if he was certain he would win, as if he was assured that someone important held all the cards.

His name was Farooq Rahman, and he had been a major, and later, lieutenant colonel in the Bangladeshi army. He had returned to Bangladesh only recently, after several years in exile in Libya. What he had done in the past was not in dispute.

Before dawn on 15 August 1975, he had led the Bengal Lancers, the army's tank unit under his command, to disarm the Rokkhi Bahini, ${ }^{1}$ a paramilitary force loyal to Sheikh Mujib. As Farooq left the Dhaka Cantonment, he had instructed other officers and soldiers to go to the upscale residential area of Dhanmondi, where Mujib lived. Soon after 5 a.m., the officers had killed Mujib and most of his family.

I had been rehearsing how to ask Farooq about his role in the assassination. I had no idea how he would react or respond. After a few desultory questions about the country's political situation, I tentatively began, 'It has been widely reported in Bangladesh that you were somehow connected with the plot to remove Mujibur Rahman from power in 1975. Would you...'

'Of course, we killed him,' he interrupted me. 'He had to go,' he added, before I could complete my hesitant, long-winded question.

Farooq Rahman thought he was a patriot. He believed he had saved the nation. The governments that followed Mujib reinforced this self-belief and perception, rewarding him and the other assassins with respectability by giving them political space, and to some, plum diplomatic assignments. Farooq himself stood in presidential elections, which he lost badly. The Oxford-trained lawyer, Kamal Hossain, who was Mujib's law minister and later foreign minister, told me, 'The impunity with which Farooq operated was extraordinary. President Ershad encouraged Farooq to return because he wanted a candidate to stand against him in the rigged elections, so that the process would seem fair.' For Ershad this was important because, as with other 
dictators, he craved legitimacy, and the opposition boycott of the elections upset his plans. He needed a contest and Farooq obliged.

Farooq was able to operate with impunity for many years because the governments that followed Mujib were not keen to prosecute the killers and in the late 1970s, during the rule of Gen. Zia, the 5th Amendment to the constitution was passed, granting them immunity.

The political landscape in Bangladesh after Mujib's murder was unstable. In its forty-four-year history, there have been several coups, and the form of government has switched from parliamentary to presidential to parliamentary again. The country has had eleven prime ministers and over a dozen heads of state, and there have been times when it has been ruled by generals, or by a caretaker government comprising unelected officials.

Mujibur Rahman's daughter Sheikh Hasina Wajed had first come to power in 1996 but her majority was precarious at that time-her party, the Awami League, had won 146 of 300 seats, and relied on the support of other parties to rule. But when she came to power with an absolute majority in 2009, Hasina was determined to redeem her father's reputation and seek justice. Her quest has larger implications for Bangladesh's citizenry. Hundreds of thousands - and by Bangladesh government estimates perhaps three million - people were killed during the 1971 war. Tens of thousands of Bangladeshis now wait for justiceto see those who harmed them and their loved ones brought to account. But the culture of impunity hasn't disappeared. Even for Sheikh Hasina, it took more than three decades before she received some measure of vindication, and one reason she was elected in 2008 was because she promised to set up tribunals to prosecute individuals accused of having committed international crimes, such as war crimes, crimes against humanity, and genocide.

Sometime in the afternoon of 27 January 2010, Mahfuz Anam received a call from a government official, saying that the end was imminent. Anam was in the newsroom of Bangladesh's leading English newspaper, The Daily Star, where he is the editor. He knew what the message meant: perhaps within hours, five men-Lt. Col. Farooq, Lt. Col. Sultan Shahriar Rashid Khan, Lt. Col. Mohiuddin Ahmed, Maj. Bazlul Huda, and army lancer A.K.M. Mohiuddin — would be hanged by the neck until they died at the city's central jail. Anam told his reporters to be prepared, and sent several reporters and photographers to cover the executions. 
'We had hints that the end was near, particularly when the relatives of the five men were asked to come and meet them, and given hardly any notice,' Anam told me during a long telephone conversation a week after the executions. 'The authorities had told the immediate families that there were no limits on the number of relatives who could come, and they were allowed to remain with them until well after visiting hours. We knew that the final hours had come,' he said.

Once the families left, the five men were sent to their cells. They were told to take a bath and offer their night prayers. Then the guards asked them if they wanted to eat anything special. An imam came, offering to read from the Quran. Around 10:30 p.m., a reporter called Anam to say that the city's civil surgeon, Mushfiqur Rahman, and district magistrate Zillur Rahman had arrived at the jail. Police vans arrived 50 minutes later, carrying five empty coffins. The paramilitary force known as the Rapid Action Battalion, took positions at various nodal points in the city that were prone to strikes and stoppages at the slightest political pretext, providing support to the regular police force to prevent demonstrations. Other leading officials came within minutes: the home secretary, the inspector general of prisons, and the police commissioner. Rashida Ahmad, who was at that time news editor at the online news agency, bdnews24.com, recalled: 'Many media houses practically decamped en masse to the jail to "experience a historic moment" firsthand.' Anam told me, 'By 11:35 p.m., we knew it would happen that night. We held back our first edition. The second edition had the detailed story.'

Bazlul Huda was the first to be taken to the gallows. He was handcuffed, and a black hood covered his face. Eyewitnesses have said Huda struggled to free himself and screamed loudly as guards led him to the brightly lit room. An official waved and dropped a red handkerchief to the ground, the signal for the executioner to proceed. It was just after midnight when Huda died. Mohiuddin Ahmed was next, followed by Farooq, Shahriar, and A.K.M. Mohiuddin. It was all over soon after 1 a.m.

Earlier that day, the Bangladesh Supreme Court had rejected the final appeal of four of the five convicts. Shahriar was the only one not to seek presidential pardon. His daughter Shehnaz, who spent two hours with her father that evening, later said: 'My father was a freedom fighter; and a man who fights for the independence of his country never begs for his life.'

Sheikh Hasina was at her prime ministerial home that night. She was informed when the executions began, she reportedly asked to be left alone 
and later offered namaz-e-shukran, a prayer of gratitude. Many people, most of them supporters of the Awami League, had gathered outside her house that night, but she did not come out to meet anybody. A few days later, she told a party convention that it was a moment of joy for all of them, because due process had been served.

Many governments oppose the death penalty on principle and consider it violates human rights, and the European Union had appealed to the Bangladeshi government to commute the sentence of Mujib's assassins. The human rights group Amnesty International had also sought clemency, while agreeing that the men should face justice. These appeals met with no response.

The mood in Dhaka was sober and subdued, although Dhaka residents spoke of celebrations in certain localities. Ahmad, who was at her news desk until late at bdnews24.com, described the mood in the newsroom as sombre. Many in the city could understand Hasina thanking God, and other politicians welcoming the closing of a dark chapter, but some felt it a bit much that parliament itself thanked God and adjourned for the day, she told me.

It had taken thirty-four years for this saga to end. The first politician to grant these men immunity was Khondaker Mostaq Ahmad, who took over as Bangladesh's president after Mujib's assassination. He had even praised the assassins, calling them 'shurjo shontan' or 'sons of the sun'. Gen. Ziaur Rahman, who later became president, confirmed their immunity and later amended the constitution to entrench this. In the years that followed, their political rehabilitation had begun. ${ }^{3}$ Lt. Col. Shariful Haq Dalim, a decorated liberation war veteran who had played a major role in the conspiracy, held diplomatic positions in Beijing, Hong Kong, and became high commissioner to Kenya, even though he was implicated in a coup attempt in 1980. Lt. Col. Aziz Pasha served in Rome, Nairobi, and Harare, where he sought asylum when Hasina first came to power in 1996. She removed him from his diplomatic post but he stayed on in Harare, and died there. (A month after the executions, Awami League activists ransacked and set afire the home of his brother in Dhaka.) ${ }^{4}$ Maj. Huda was briefly a member of parliament, and also served as diplomat in Islamabad and Jeddah.

Other conspirators at various times served Bangladeshi missions in Beijing, Buenos Aires, Algiers, Islamabad, Teheran, Kuwait, Abu Dhabi, Bangkok, Lagos, Dakar, Ankara, Jakarta, Tokyo, Muscat, Cairo, Kuala Lumpur, Ottawa, and Manila. The government said it would now try to bring the surviving officers back to Bangladesh from the countries where some of the conspirators 
reportedly continued to live. These were often identified as the United States, Canada, Pakistan, South Africa, Thailand, and Kenya. They have been tried in absentia and some face execution.

Bringing all of them back is not going to be easy for Bangladesh, because some countries where they reportedly live, like Canada and South Africa, have abolished the death penalty, and Kenya has placed a temporary moratorium on the death penalty. They are unlikely to extradite them, unless Bangladesh guarantees that they will not be executed. Bangladesh is unlikely to offer such guarantee.

Bangladesh is among fifty-eight countries (including India) that retain the death penalty. In 2008, five people were executed in Bangladesh. Bangladeshi human rights lawyers have found it hard to challenge the death penalty on a matter of principle because there is public support for the death penalty in Bangladesh. Lawyers do appeal individual cases, but there is no concerted major human rights campaign against the death penalty. There are also political compulsions. One human rights activist told me, 'We are against [the] death penalty but the dilemma is that we are in a country where life imprisonment really means imprisonment guaranteed only until your party comes to power. The death penalty is almost seen as the only way to guarantee justice for such a grisly crime.'

Grisly, it certainly was. This is what happened.

Dhanmondi in 1975 had not changed much from how it looked in the 1950s, soon after Pakistan's independence, when Dacca, as the city was then known, was the provincial capital of East Pakistan. The roads were lined with two-storey houses, the traffic quiet and unhurried. Today, there are multistorey buildings, English-medium schools, new universities, shopping malls and hookah bars to lure younger crowds. Back in 1975, the area was quieter. In the evening, people strolled along the periphery of the large lake in the middle of the neighbourhood and at night you could hear the tinkling bells of cycle rickshaws.

On 15 August 1975, before dawn, 700 soldiers left their barracks and headed for the three homes where Mujib and his family lived. Everyone was still asleep at Mujib's house, \#677 on Road 32. They first attacked the home of Abdur Rab Seraniabat, Mujib's brother-in-law, at 27 Minto Road. Mujib heard about the attack. Seraniabat was a minister in Mujib's government. 
Mujib called his personal assistant, Mohitul Islam, who was at his desk, and asked him to call the police immediately.

Mohitul tried calling the police, but was alarmed to find that the phones weren't working. When he used another secure line to call the telephone exchange, the person at the other end said nothing.

Mujib snatched the phone and shouted into the mouthpiece. 'What's going on?' he asked.

At the time soldiers arrived at Mujib's house, the guards outside were hoisting the national flag. They were stunned to find army officers rushing in through the gate, ordering them to drop their weapons and surrender. A few shots were fired.

Maj. Bazlul Huda entered Mujib's house with several soldiers. A frightened servant woke up Mujib's son Kamal, who got dressed and came down. Huda took out his gun and pointed it at Kamal even as Mohitul tried telling Huda that it was Kamal, Mujib's son. But before he could complete the sentence there was a loud burst of gunfire and Kamal fell down, dead. Huda heard Mujib's voice at the top of the staircase and ran to face him.

'What do you want?' Mujib asked Huda, whom he recognized.

The soldiers pulled their triggers, spraying Mujib with dozens of bullets. Mujib's body was thrown back and then forward, gushing blood which splattered the stairs and the wall. He was dead by the time his body stopped tumbling down the stairs. Before his burial the following day at his birthplace, Tungipara, the imam noticed at least ten bullets still lodged inside Mujib's body.

The killers then went inside the house, and one by one, killed everyone they could find: Mujib's wife, Fazilatunnesa; Kamal's wife, Sultana; Mujib's other son, Jamal, and his wife Rosy; and Mujib's brother Naser, who was heard pleading, 'I am not in politics.'

Then they saw Russell, Mujib's 10-year-old son, who was crying, asking for his mother. He, too, was killed.

Around the same time, another group of soldiers had killed Mujib's brotherin-law Seraniabat at his home, and a third group had murdered the family of Fazlul Haque Moni, Mujib's nephew, an influential Awami League politician who lived on Road 13/1, about two kilometres away from Mujib's home.

Mahfuz Anam lived across the Dhanmondi Lake at that time, and had a clear view of Sheikh Moni's house. 'I saw what happened,' he recalled. 'Early that morning I was awakened by the sound of firing. I got up. My room was on the side of the lake. I ventured out to the boundary wall. I 
saw troops enter Sheikh Moni's house. I heard plenty of firing, followed by screaming. I heard shots - some random, some from sub-machine guns. I saw the troops leave the house. It was all over in four to six minutes. I could hear the people inside groaning; it continued for some time.'

The junior officers' coup had proceeded exactly as planned. There had been no resistance from the moment Huda and his team had reached Mujib's home. After taming the Rakkhi Bahini, Farooq arrived at Mujib's gate, eager to know what had happened there. Huda told him calmly, 'All are finished.'

When we met a decade after those killings, I asked Farooq: 'And the 10-year-old boy: did he have to be killed?'

'It was an act of mercy killing. Mujib was building a dynasty; we had to finish off all of them,' he told me with a degree of finality, his arm slicing ruthlessly in the air, as if he was chopping off the head of someone kneeling in front of him. There was no mercy in his eyes, no remorse, only a hint of pride.

The junior officers who had conspired to assassinate Mujib had tried killing the entire family, but Mujib's two daughters, Hasina and Rehana, were in Germany, where Hasina's husband, M. A. Wazed Miah, a nuclear scientist, was a researcher at a laboratory (he died in May 2009). Kamal Hossain was at that time on an official visit to Belgrade. Kamal Hossain told me: 'I first heard there had been a coup. We received more information from agency reports which were conveyed to me by the officials of the Yugoslav foreign ministry. We heard about Mujib's death, then we heard about the other family members. My immediate concern was Hasina's safety.' He met her in Bonn and decided to sever his relations with the new government. In his autobiography Hossain writes: 'I regarded my relations with the government to have ceased the moment power had been seized through the assassination and coup... I firmly declined to accept any assignment... by the [new] government. ${ }^{5}$ He handed in his official passport to the ambassador, and left for England, because it was easier to get information there. In London he handed in his diplomatic passport and obtained an ordinary passport, informing the High Commission that he was severing relations with the new government. Hasina, too, could not have gone back. She was granted asylum in India and lived in New Delhi with her husband until 1981. Hossain returned to Dhaka in 1980.

In October 1986, I visited Mujib's house, the mute witness to the ghastly events of that dawn. As if to ensure that no one should forget the tragedy, Sheikh Hasina, who showed me around, had made only minimal changes to the house, preserving the crime scene. The bare walls bore dozens of bullet 
marks. Shattered glass lay on the ground of what was once Mujib's library. On the staircase where Mujib was shot, and on the wall which he had tried to grip for support as he fell, darkened blood stains were still visible. She pointed these out to me.

Mujib was 55 when he was killed. He had been in and out of Pakistani jails, and was widely regarded - and initially revered - as Bangladesh's founding father. At the time of Partition of British India in 1947, what is now known as Bangladesh became the eastern wing of Pakistan. The two parts of Pakistan were separated by thousands of kilometres of Indian territory. Pakistan was supposed to become the home for the Muslims of the subcontinent, even though many Muslims chose to stay on in India. Islam united the two parts, east and west, but culture, language, and the idea of what made a nation would divide them. The eastern half was more populous, and its leaders complained of insufficient attention and inadequate resource allocation. Punjabis dominated the Sindhis, Baluchis, and Pathans in the west, and they had even less regard for their Bengali compatriots in the east. Bingo was the pejorative term West Pakistanis used to describe East Pakistanis.

Things came to a head in 1970, when in nationwide elections the Awami League won enough seats in the eastern wing to form a national government. Mujib should have been invited to become Pakistan's prime minister, but the generals and politicians in the west had other plans. They engaged the Awami League in interminable negotiations even as Pakistan's ruler at the time, Gen. Yahya Khan, quietly sent troops to the east, and later appointed a governor called Gen. Tikka Khan, who had express instructions to crush Bengali nationalism. Many Bangladeshis remember planeloads of young men arriving on flights from the west. They were military men but not in uniform, and they did not carry any weapons. Meanwhile, Pakistan's navy was shipping weapons through the Chittagong port, keeping Bengali officers in the dark, and secretly arming the men who had landed in Dacca.

The military crackdown began on 25 March 1971, as the Pakistani army brutally attempted to trounce Bengali aspirations. Mujib was jailed in West Pakistan. In the east, hundreds of thousands were killed, and millions of refugees made their way to India. A civil war followed, and India aided the Mukti Bahini, as Bangladeshi freedom fighters were called. In early December, Pakistan attacked India on its western front; India retaliated, and its troops defeated Pakistan on both fronts within a fortnight. Indian troops entered the capital, and thousands of Pakistani troops surrendered. A few weeks later 
Mujib returned to the Tejgaon airport. A sea of humanity greeted the leader of the new nation, Bangladesh.

Three-and-a-half years later, Farooq and his men annihilated most of Mujib's family. 'Even dogs didn't bark when we killed Mujib,' Farooq told me.

Sheikh Mujibur Rahman had squandered his unprecedented goodwill for two reasons. First, he could not meet the phenomenal expectations Bangladeshis had from his leadership. His closeness to India worried some Bangladeshis who feared a Hindu-majority India would dominate the new nation. Many Bangladeshis had fought for an independent Pakistan during the last years of the Indian freedom struggle and did not see India as a friendly neighbour. At the time of independence, the Muslim League, which was at the forefront for the demand of an independent Pakistan had commanded huge support in the province of Bengal. When Bangladesh became independent in 1971, some within Bangladesh still had residual feelings for a Pakistani identity. Indeed, Lawrence Lifschultz, an American reporter for the magazine Far Eastern Economic Review who was based in Dacca in 1974, remembers the day when Pakistan's prime minister, Zulfikar Ali Bhutto, visited Bangladesh for the first time since Bangladesh's independence. As Bhutto's motorcade travelled from the airport into central Dhaka, a section of the crowd lining the street shouted, 'Bhutto Zindabad'.

Lifschultz thought this was rather bizarre, but disenchantment with the new nation and nostalgia for Pakistan wasn't surprising. By mid-1974, Bangladesh was reeling from a widespread famine that experts believe was at least partly due to political incompetence. Citizens were also stunned by the ostentatious weddings of Mujib's sons Kamal and Jamal which took place during an economic crisis. Food distribution had failed nationwide, and people were forced to sell their farm animals to buy rice. Thousands of poor people left their villages looking for work in the cities. Irene Khan, a refugee law and human rights lawyer who heads the International Development Law Organization in Rome and who headed Amnesty International from 2001 to 2009 , was a schoolgirl in the early 1970s. She recalls hungry voices clamouring for food outside the gates of her family home every day.

Clearly, there were Bangladeshis disillusioned with freedom, even though their fate under Pakistani rule would have been no better. One reason the Awami League won the December 1970 elections so handsomely was because the federal government had failed miserably in providing relief to its eastern wing after a devastating cyclone had killed many in the previous month. And 
yet, to Lifschultz, the cheering of Bhutto seemed particularly perverse, given the circumstances of Bangladesh's birth. With public criticism over the mass starvation growing, Mujib had clamped down on dissent. He had abolished political parties and created one national party called Bangladesh Krishak Sramik Awami League (BAKSAL, or the Bangladesh Peasants, Workers and People's League); a few free-thinking experts who did not agree with his policies left advisory and other positions they held with the government; he nationalized newspapers (closing most), and allowed only two each, which toed the party line - in Bangla and in English. He stifled dissent within the party, made huge inroads into the constitution, and declared himself president. A pliant parliament passed these monumental constitutional changes with minimal debate.

Farooq was outraged when we spoke in 1986. He claimed Mujib was threatening politicians who disagreed with him. He alleged that Mujib's son Kamal had raided a bank. Army personnel had to go around carrying personal weapons, afraid that their wives would get kidnapped, he claimed. He sounded livid when he talked of how Mujib had undermined the country's democratic institutions. He said, 'How do you pass an amendment in Parliament which abolishes party membership in just eleven minutes? No discussions, nothing!' Bangladesh, he feared, was becoming a colony of India, and he feared for his South Asian neighbours. 'All other members of SAARC [South Asian Association for Regional Cooperation] are worried that they will end up as part of the Indian Empire,' he said. He called himself a freedom fighter, and said he had to stop that. 'I tried to save the country,' he told me, his tone rising, 'Mujib had changed the constitution so that the court could not do a thing [to stop him]. All power was with the president.'

None of Farooq's explanations justified the terrible manner in which Sheikh Mujib and his family were killed. But the famine and the increasingly authoritarian Awami rule partly explain why there was little outward expression of grief after his assassination. That, and fear. When the new president, Khondaker Mostaq Ahmad, called the assassins shurjo santan, the signal was clear. The king was dead; long live the king. But many Bangladeshis, to this day, feel revolted by the brutality of killing not only Mujib, but most of his family. Many of them felt the death penalty for the assassins was justified.

Mujib's assassins were sentenced to death as early as in 1998. They appealed, but higher courts upheld the sentence in April 2001 and November 2009 respectively. They sought a Supreme Court review, and later, four of the five 
applied for presidential pardon. While the government meticulously followed the constitutional procedures, many have noted the speed with which the final appeals were dealt with.

Why had Farooq returned to Bangladesh in 1986? Could he have foreseen that one day he would have to reckon with his past acts? When I had asked him, his response was dismissive, 'Go to the people and talk about me. For eleven years I have been gagged nationally and internationally, so I had good reason to want to go to the people. I think my ideas are more popular than those of all the other political leaders.'

I reminded him that he had won only 4.51 per cent of the popular vote.

'If we are given free and fair elections, I can probably win. Ershad has won the elections but lost the politics,' he asserted.

Farooq had spent a decade in Libya. 'Gen. Zia sent us there. We were to be absorbed in their army but I flatly refused. I was not a mercenary. Transfer or secondment is one thing, being a mercenary is another matter altogether. I declined a diplomatic assignment as well. I suppose Gaddafi liked me because of my principled stand,' he told me.

I asked him if he liked Muammar Gaddafi, the Libyan strongman who would himself meet a violent death in 2011.

His response was elliptical: 'What others think of you is irrelevant. What America thinks of you or India thinks of you is irrelevant. What matters to me is what Bangladeshis think of me. Most Bangladeshi leaders are only bothered about what the world thinks of them. That's why I am admired, because I only care about what my people think.'

At 9:25 a.m. on 26 January 2010, a four-member special bench of the Supreme Court's appellate division met to decide on the review petition from the assassins. They rejected it two minutes later. Senior civil servants of the law and home ministry met at noon, and discussed the issue for three hours. Farooq, who had until then resisted writing his mercy petition, did so that afternoon. Officials received it and dispatched his petition to the office of the president within minutes. At 7:30 p.m., President Zillur Rahman rejected the petition. ${ }^{6}$ The quick turnaround of the documents was remarkable, although procedurally every step was taken properly. One lawyer remarked, 'What you saw wasn't due process; it was process with undue speed.'

The hangings occurred soon after midnight. 